\title{
Induced Mutagenesis in Yellow Flowering Marigold with Colchicine in Hydrogen Peroxide
}

\author{
I Gede Ketut Susrama* and Ketut Ayu Yuliadhi \\ Agroecotechnology Department, Faculty of Agriculture, Udayana University, \\ Jl. P.B. Sudirman, Denpasar 80232, Bali, Indonesia. \\ *Corresponding author: ketutsusrama@unud.ac.id
}

\begin{abstract}
Marigold flower has many benefits in many aspects of life in Bali Island (Indonesia) including often used in religious ceremonial activities. For controlling plant pests and diseases, marigold is planted on the sidelines or on the edge of a land as an attractant crop to invite natural enemies and marigold also can produce certain substance which can reduce the incidence of nematode. In inducing mutagenesis in this research, the seeds of marigold were soaked in solution of colchicine with hydrogen peroxide as its solvent. The results of this research indicated that the treatments caused the formation of chlorophyll mutant and an increase in the length of flower diameter. Both the control and treated plant samples were attacked by leaf miner, giant land snail, virus-like disease and botrytis flower blight disease.
\end{abstract}

Keywords: mutagenesis; marigold; colchicine in hydrogen peroxide; chlorophyll mutant

\section{INTRODUCTION}

Marigold (Tagetes erecta $\mathrm{L}$ ) is widely cultivated in the world for many kinds of uses such as for religious ceremony, offerings, intercrop, ornamental plant, landscape plant, companion plant, pest control plant and as medicinal plant. Benefit of marigold as intercropping was reported by Silveira et al [1] that the presence of marigold could increase species richness index and Shannon's diversity index in onion cultivation. Furthermore, Khan et al [2] stated that marigold is resistance biochemically against nematode such as root-knot nematode. In addition, Priyanka et al [3] mentioned that marigold can be used as a cover crop and it could produce alpha terthyenil which can reduce incidence of root-knot nematode. Marigold also contains various potential ingredients for manufacturing ethnobotanical drugs [4] for example is an alternative medicine used as a medicinal ingredient for podiatric treatment [5].

Colchicine in aqueous solution that has been used as a chemical agent in inducing mutagenesis in various plants for quite a long time, it was since year 1940. In our research instead of using distillate water, we use hydrogen peroxide as the solvent. This research was aimed to find any beneficial morphological changes of colchicine in hydrogen peroxide treated marigold and to identify plant pests and diseases incidence as a preliminary data for inferring whether the treatment could increase its resistance.

\section{METHODS}

Marigold seeds used in this research were F1 Cassanova hybrid variety produced by PT. Makmur
Pertiwi Company with a distribution permit from Indonesian Ministry of Agriculture Number 077/Kpts/SR/SR.120/D.2.7/8/2013. Seeds are treated with different concentration of colchicine in hydrogen peroxide which were $0.0001 \%$ and $0.0005 \%$ for 12 hours. Control seeds were treated with only hydrogen peroxide also for 12 hours. Each seed was planted in a pot and each treatment was replicated ten times. During observation period, we observed any morphological changes occurred and any incidence of pests and diseases during plant growth. The percentage of attacked plant (\% AP) or percentage of attacked flower (\% AF) was use for evaluate the resistance reaction of marigold.

\section{RESULTS AND DISCUSSION}

\section{Chlorophyll mutant}

Chlorophyll mutant was first occurred in 16 days old $0.005 \%$ treated marigold seedling and only one seedling in ten seedlings showed phenotypic leaf mutation. On day 28 mutated part of the seedling look like (Figure 1). With only one treatment of colchicine in hydrogen peroxide, it was just a small proportion of marigold leaves turn yellow. If a multistep mutagenesis induction technique is applied, it is likely that even more parts of marigold leaves have mutation and its leaf color turn to yellow. In food plants, phenotypic changes in the form of chlorophyll mutants are generally almost of less or no economic value, however in ornamental plants can increase aesthetic value and also it will increase its genetic variation. The change will give certain beauty or another nuance to the overall appearance of marigold plant and it will become a new creation of marigold species. Kolar et al [6] illustrated ten 
classifications of chlorophyll mutant i.e. albina green, aurea, chlorina, viridis, yellow viridis, tigrina, striata, maculata and variegated. Selvan and Raju [7] described 4 basic types of chlorophyll mutant namely albino, xantha, chlorina and variegated. The mutant chlorophyll from our research is belong to variegated chlorophyll mutant category. The appearance of chlorophyll mutants can be used as a reference to the relationship with an efficient treatment dose in developing genetic variation as mentioned by Goyal et al [8] that occurrence of mutation in chlorophyll indicates the real influence of a mutagen on plant genetic. a.

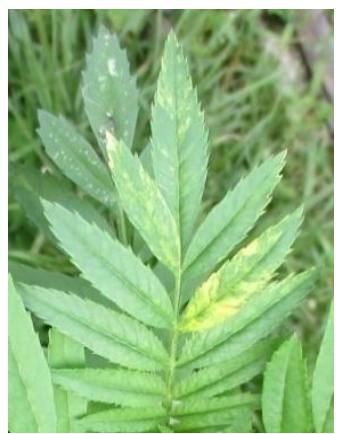

d.

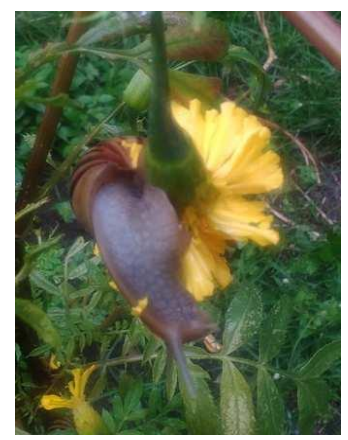

b.

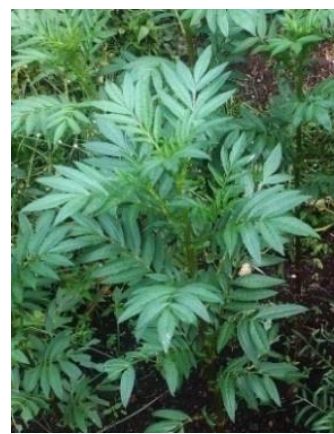

e.

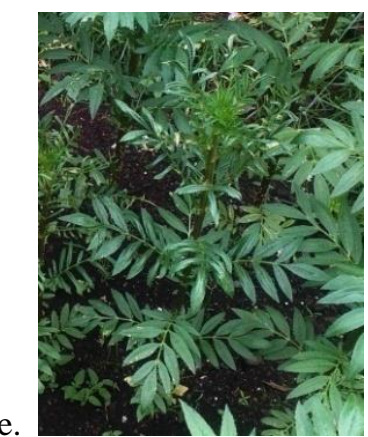

c.
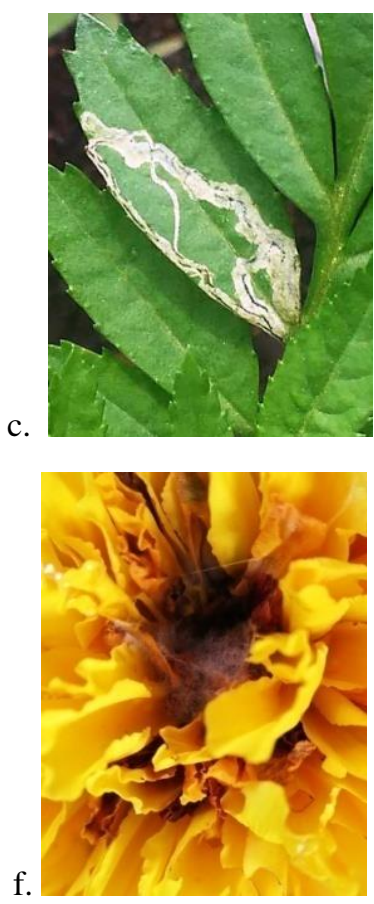

Figure 1. a. Marigold chlorophyll mutant, b. healthy marigold plant, c. leaf miner, d. giant land snail, e. virus-like disease, f. botrytis flower blight disease

\section{Increase in flower diameter}

Based on observation results of flower diameters as seen in Table I, it can be calculated that the increase in diameter of marigold flower compared to control plant sample in average was $7.75 \%$ by $0.0001 \%$ colchicine in hydrogen peroxide treatment and $12.23 \%$ by $0.0005 \%$ treatment. Colchicine is a known natural substance that extracted from Colchicum autumnale. It is a substance that could increase the number of chromosome or inducing polyploidy in plants (Bates [9]; Dewi and Pharmawati [10]) and $\mathrm{Wu}$ et al [11] mentioned that a common effect of colchicine is increasing polyploid plant size. The increasing marigold flower size increases its price due to the market prefers bigger flower size.

TABLE I

IN FLOWER DIAMETER

\begin{tabular}{|c|c|c|c|c|c|c|c|c|c|c|c|c|c|c|c|c|}
\hline \multirow{2}{*}{$\begin{array}{l}\text { Description } \\
\text { Control }\end{array}$} & \multicolumn{13}{|c|}{ Flower diameters $(\mathrm{cm})$} & \multirow{2}{*}{$\begin{array}{c}\text { Average } \\
6.35\end{array}$} & \multirow{2}{*}{$\begin{array}{c}\text { Diameter } \\
\text { increase }(\mathrm{cm})\end{array}$} & \multirow[t]{2}{*}{ In percent } \\
\hline & 6.5 & 6.3 & 5.8 & 6.2 & 7.1 & 6.7 & 5.5 & 7.0 & 6.5 & 7.0 & 5.5 & 6.0 & 6.5 & & & \\
\hline Treatment 1 & 6.0 & 6.9 & 7.0 & 7.0 & 6.0 & 7.5 & 6.9 & 7.1 & 6.9 & 6.7 & 7.0 & 8.0 & 6.0 & 6.85 & 0.49 & 7.75 \\
\hline Treatment 2 & 7.0 & 6.0 & 7.0 & 6.0 & 6.7 & 6.0 & 7.4 & 6.5 & 7.0 & 9.0 & 7.1 & 8.9 & 8.1 & 7.13 & 0.78 & 12.23 \\
\hline
\end{tabular}

Note: Treatment 1: colchicine in hydrogen peroxide treatment $0.0001 \%$. Treatment 2 : colchicine in hydrogen peroxide treatment $0.0005 \%$.

\section{Leaf miner incidence}

On 28 days old marigold plant, leaf miner was the first pest incidence occurred and the symptom of leaf miner attack a leaflet shows in Figure 3. Leaf miner reduce the beauty of marigold in its function as an ornamental plant besides it could reduce plant photosynthesis level due to decreased leaf's chlorophyll content. In this research, we found that leaf miner incidence occurred in treated sample plants and in control plants as well and its percentages were higher in treated samples (Table II). 
Based on those results, we presume that the carried-out treatment did not cause an increase of marigold resistance against leaf miner. More evidence needed for confirmation. Marigold is used to use as trap crop for controlling leaf miners indicating marigolds are plant that are susceptible to leaf miner. Together with chrysanthemum, Variya and Patel [12] planted marigold as trap plant against chrysanthemum leaf miner (Liriomyza trifolii Burgess) in tomato cultivation showed that preference of leaf miner for marigold is relatively high although lower than chrysanthemum. Colchicine have reported in some publications could change the thickness of plant cell wall. Initially we suspected that changes in cell wall thickness would increase marigold resistance to leaf miner. However, in this research both concentration of colchicine in hydrogen peroxide treated marigold plants and control marigold plant samples were attacked by leaf miner showed that marigold treated with colchicine in hydrogen peroxide remain susceptible to leaf miner.

\section{Giant land snail incidence (Achatina fulica Bowditch)}

Marigold plant that usually function as a deterrent plant for various species of pests, based on the result of our research for giant land snail was not the case. Against giant land snail, marigold was not a deterrent plant at all. We did not observe giant land snail every night but once a day at day time. Data was recorded by counting marigold that show a partial or whole flower's petal cut off. The attack of giant land snail (Figure 4) were mostly at night or at the day time after heavy rain. Giant land snail trace of attacks occurred both in plants grown from seeds treated with colchicine in hydrogen peroxide and also in control plants (Table III). More trace of attacks was found in treated samples plants comparing to in control. For now, we infer the results of this research showed that treatment of colchicine in hydrogen peroxide did not elevate marigold resistance against giant land snail. Considering that there were not any other similar research results available for comparison, more evidence should be presented by repeating similar research in another location.

\section{Virus-like disease incidence}

Virus-like incidence were identified 43 days after planting with symptoms on leaf i.e. deformation, downward curling and shoestring (Figure 5). Growth of infected plants were then stunted; its leaf dried out and failed to produce flower. Virus-like disease attack occurred in $0.0005 \%$ colchicine in hydrogen peroxide treated marigold plants. Among ten marigold plants, three plants were found infected. The disease symptom did not occur in $0.0001 \%$ colchicine in hydrogen peroxide treated marigold plants and in control plants (Table IV). We infer that results of our research indicated that colchicine in hydrogen peroxide treatment did not show a potential positive effect in increasing marigold resistance to viruslike disease. Reports concerning incidence of virus-like disease in marigold were published by Ara et al [13] and Sultana et al [14].

TABLE II.

LEAF MINER INCIDENCE

\begin{tabular}{lccccccccc}
\hline \hline & \multicolumn{3}{c}{ 4th week } & \multicolumn{3}{c}{ 6th week } & \multicolumn{3}{c}{ 8th week } \\
\cline { 2 - 10 } Description & $\begin{array}{c}\text { Plants } \\
\text { observed }\end{array}$ & $\begin{array}{c}\text { Attacked } \\
\text { plants }\end{array}$ & $\begin{array}{c}\text { In } \\
\text { percent }\end{array}$ & $\begin{array}{c}\text { Plants } \\
\text { observed }\end{array}$ & $\begin{array}{c}\text { Attacked } \\
\text { plants }\end{array}$ & $\begin{array}{c}\text { In } \\
\text { percent }\end{array}$ & $\begin{array}{c}\text { Plants } \\
\text { observed }\end{array}$ & $\begin{array}{c}\text { Attacked } \\
\text { plants }\end{array}$ & $\begin{array}{c}\text { In } \\
\text { percent }\end{array}$ \\
\hline Control & 10 & 0 & 0 & 10 & 1 & 10 & 10 & 5 & 50 \\
Treatment 1 & 10 & 0 & 0 & 10 & 2 & 20 & 10 & 6 & 60 \\
Treatment 2 & 10 & 1 & 10 & 10 & 2 & 20 & 10 & 7 & 70 \\
\hline
\end{tabular}

TABLE III.

GIANT LAND SNAIL INCIDENCE

\begin{tabular}{lccccccccc}
\hline \hline & \multicolumn{3}{c}{ 8th week } & \multicolumn{3}{c}{ 9th week } & & \multicolumn{2}{c}{10 th week } \\
\cline { 2 - 10 } Description & $\begin{array}{c}\text { Flowers } \\
\text { observed }\end{array}$ & $\begin{array}{c}\text { Flowers } \\
\text { with trace } \\
\text { of attacks }\end{array}$ & $\begin{array}{c}\text { In } \\
\text { percent }\end{array}$ & $\begin{array}{c}\text { Flowers } \\
\text { observed }\end{array}$ & $\begin{array}{c}\text { Flowers } \\
\text { with trace } \\
\text { of attacks }\end{array}$ & $\begin{array}{c}\text { In } \\
\text { percent }\end{array}$ & $\begin{array}{c}\text { Flowers } \\
\text { observed }\end{array}$ & $\begin{array}{c}\text { Flowers } \\
\text { with trace } \\
\text { of attacks }\end{array}$ & $\begin{array}{c}\text { In } \\
\text { percent }\end{array}$ \\
\hline Control & 7 & 0 & 0 & 15 & 1 & 7 & 25 & 2 & 8 \\
Treatment 1 & 8 & 0 & 0 & 17 & 2 & 12 & 25 & 3 & 12 \\
Treatment 2 & 10 & 0 & 0 & 19 & 3 & 16 & 27 & 5 & 19 \\
\hline
\end{tabular}


TABLE IV

DISEASE INCIDENCE

\begin{tabular}{lccccccc}
\hline \hline Description & \multirow{2}{*}{$\begin{array}{c}\text { Plants } \\
\text { observed }\end{array}$} & $\begin{array}{c}\text { 6th week } \\
\text { Infect } \\
\text { plants }\end{array}$ & $\begin{array}{c}\text { In } \\
\text { percent }\end{array}$ & $\begin{array}{c}\text { Infected } \\
\text { plants }\end{array}$ & $\begin{array}{c}\text { In } \\
\text { percent }\end{array}$ & $\begin{array}{c}\text { Infected } \\
\text { plants }\end{array}$ & $\begin{array}{c}\text { In } \\
\text { percent }\end{array}$ \\
\hline Control & 10 & 0 & 0 & 0 & 0 & 0 & 0 \\
Treatment 1 & 10 & 0 & 0 & 0 & 0 & 0 & 0 \\
Treatment 2 & 10 & 3 & 30 & 3 & 30 & 3 & 30 \\
\hline \hline
\end{tabular}

TABLE V

BOTRYTIS FLOWER BLIGHT DISEASE INCIDENCE

\begin{tabular}{lccccccccc}
\hline \hline \multirow{3}{*}{ Description } & \multicolumn{3}{c}{ 8th week } & \multicolumn{3}{c}{ 9th week } & \multicolumn{3}{c}{ 10th week } \\
\cline { 2 - 10 } & $\begin{array}{c}\text { Flowers } \\
\text { observed }\end{array}$ & $\begin{array}{c}\text { Infected } \\
\text { flowers }\end{array}$ & $\begin{array}{c}\text { In } \\
\text { percent }\end{array}$ & $\begin{array}{c}\text { Flowers } \\
\text { observed }\end{array}$ & $\begin{array}{c}\text { Infected } \\
\text { flowers }\end{array}$ & $\begin{array}{c}\text { In } \\
\text { percent }\end{array}$ & $\begin{array}{c}\text { Flowers } \\
\text { observed }\end{array}$ & $\begin{array}{c}\text { Infected } \\
\text { flowers }\end{array}$ & $\begin{array}{c}\text { In } \\
\text { percent }\end{array}$ \\
\hline Control & 7 & 0 & 0 & 15 & 0 & 0 & 25 & 0 & 0 \\
Treatment 1 & 8 & 0 & 0 & 17 & 0 & 0 & 25 & 3 & 12 \\
Treatment 2 & 10 & 0 & 0 & 19 & 0 & 0 & 27 & 4 & 15 \\
\hline
\end{tabular}

\section{Botrytis flower blight incidence}

Botrytis flower blight disease was identified at 70 days after planting. The characteristic feature of botrytis flower blight symptom (Figure 6) was appearance of grayish mold on the wet infected tissue. Infected flower turns brown, shrink and then dry up. Once of botrytis flower blight incidence in marigold was reported by Aktaruzzaman et al [15]. In our research, we found there were incidences of botrytis flower blight disease on colchicine in hydrogen peroxide treated marigold. In $0.0001 \%$ treated marigold, 3 flowers were infected from a total of 25 flowers (12\%) and in $0.0005 \%$ hydrogen peroxide treated marigold, 4 flowers were infected from 27 flowers $(15 \%)$ and all control samples ( 25 flowers) were free from botrytis flower blight disease incidence (Table V). Based on the result, we infer that treatment of colchicine in hydrogen peroxide did not have any promising potential effect on marigold resistance against botrytis flower blight disease. For more evidence, further research should be done.

\section{CONCLUSION}

Based on results of our research, we concluded that the treatment of colchicine in hydrogen peroxide could induced mutagenesis in yellow flowering marigold resulted in variegated chlorophyll marigold mutant and increase its flower diameter. We infer that the treatments did not improve yellow flowering marigold resistance against giant land snail, leaf miner, botrytis flower blight and virus-like disease.

\section{ACKNOWLEDMENTS}

We express our highest gratitude and appreciation to all colleges and friends that we couldn't mention here one by one who have deigned providing assistance in the form of research materials as well as financial support and moral support as long as our struggle in research preparation, plant samples observation, and in writing publication of this research.

\section{REFERENCES}

[1] Claudio SPL, EB Filho, LSR Pierre, FSC Peres, JNC Louzada. 2009. Marigold (Tagetes erecta, L) as an attractive crop to natural enemies in onion fields. Sci. Agric. (Piracicaba, Braz.), 66(6): 780-787.

[2] Rahman KM, H Rizvi, RA Ansari. 2013. Role of salicylic acid and phenols in the resistance of Tagetes species against Meloydogyne incognita. Indian J. Nematology, 43(1): 82-85.

[3] Dixit P, T Salini, VK Navneet. 2013. A brief study on marigold (Tagetes species): A review. Int. Res. J. Pharm, 4(1): 43-48.

[4] Pankaj G, N Vasudewa. 2012. Marigold, a potential ornamental plant drug. Hamdard Medicus, 55(1): 45-59. 
[5] Robert HA, TC Vlahopic, MT Khan. 2008. The use of marigold therapy for podiatric skin conditions. The foot \& ankle J, 1(7): 1 .

[6] Firdose KR, SR Ghatge, MS Nimbalkar, GB Dixit. 2015. Mutational changes in Delphinium malabaricum (HUTH.) MUNZ: a potential ornamental plant. J. Horti. Res, 23(2): 5-15.

[7] Anbu SY, CV Raju. 2017. Chlorophyll mutation induced in rice by chemical mutagens. Plant archives, 17(1): 641-642.

[8] Sonu G, MR Wani, S Khan. 2019. Frequency and spectrum of chlorophyll mutations induced by single and combination treatments of gamma rays and EMS in urdbean. Asian J. Biol. Sci, 12(2): 156-163.

[9] Bates HG. 1939. Polyploid induced by colchicine and its economic possibilities. Nature, 3642: 315316.

[10] Pharmawati, Dewi. 2018. Chromosome doubling in marigold. Biosfera: A scientific journal in bioscience 35(3): 153-157. (In Indonesian language).
[11] Jin WH, AR Ferguson, BG Murray, Y Jia, PM Datson, Z Zhang. 2011. Induced polyploidy dramatically increase in size and alters the shape of fruit in Actinidia chinensis. Annals of botany, 109: 169-179.

[12] Variya MV, JJ Patel. 2012. Evaluation of chrysanthemum and marigold as trap crops against leaf miner (Liriomiza trifolii Burgess) in tomato. AGRES-An intern, 1(4): 514-521.

[13] Ara RM, MMH Masud, AM Akanda. 2012. Detection of plant viruses in some ornamental plants that acts as alternate hosts. The Agriculturists, 10(2): 46-54.

[14] Sultana R, AM Akanda, MAS Haque, A Majumdar, MAZA Munsur. 2014. An investigation to virus-like diseases of marigold. J. Bios Agric Res, 2(1): 23-35.

[15] Aktaruzzaman MD, T Afroz, KB Sup, SH Dong. 2018. First report of gray mold caused by Botrytis cinerea on marigold (Tagetes erecta) in Korea. Plant Disease. American Phytophatological Society 